\title{
Rakshak - An IoT Based Wearable Device for Women Safety
}

\author{
Ambika Singhal, Shreyans Jain, Keshav Agarwal
}

\begin{abstract}
Women safety is a rising concern in many parts of the world. Crimes against women are increasing at an alarming rate. To counter this situation, a technology driven solution with the help of latest technological advancements can be developed. The aim is to develop an IoT based wearable device which works on the concept of voice recognition and allow women in the case of emergency. The device can send SOS messages to nearby help centers and relatives based on the person's location when it is activated. The device can also collect evidence for further legal procedures and save them in a remote storage. The concepts of Internet of Things (IoT), Voice Recognition and Cloud Computing are used to achieve this. The objective is to use these concepts to develop a working prototype of a smart safety device for women that can help them in such situations and prevent such incidents from taking place. 'Rakshak' is an IOT based solution, which will help us to combat these situations effectively. It contains a concealed GSM, GPS, camera, microphone, and voice recognition module. The woman can activate a sequence of events using a voice command. The voice command will send out an SOS signal to contact list, and nearby authorities. The authorities can rush to the location of the incident and prevent it. The camera will start recording as soon as the voice command is activated, and this data will be sent to cloud storage. In case an attack takes place, the footage of this camera will serve as evidence against the attacker. In addition to preventing the incident, this device may create a sense of fear in their minds which may reduce the frequency of such incidents. Thus, this solution can be applicable as a wearable security device in different domains and can be used on a large scale to ensure women safety.
\end{abstract}

Keywords: Cloud Storage, Internet of Things, Nearest Help Center contact, Storing evidence, Voice Activation, Women Safety

\section{INTRODUCTION}

The problem of women's safety is a major issue in the world. With the advent of technology, the aim is to find the solution of the same using the concepts of the Internet of Things and Cloud Technology. Internet of things enables the system to communicate with the Internet of Things helps us to interact with the real world and process real-world cues and scenarios to get an output that assists humans and other technologies [1]. Internet of

Revised Manuscript Received on April 25, 2020.

* Correspondence Author

Ambika Singhal*, Computer Science, Vellore Institute of Technology, Vellore, India. Email: ambika.singhal99@gmail.com

Shreyans Jain, Computer Science, Vellore Institute of Technology, Vellore, India. Email: shreyans241298@gmail.com

Keshav Agarwal, Computer Science, Vellore Institute of Technology, Vellore, India. Email: agarwalkeshavaa@gmail.com

(c) The Authors. Published by Blue Eyes Intelligence Engineering and Sciences Publication (BEIESP). This is an open access article under the CC BY-NC-ND license (http://creativecommons.org/licenses/by-nc-nd/4.0/)
Things is a system of uniquely identifiable components which communicate with each other, share data, and allow users to directly or indirectly interact with the physical world. This technology can be used to get location information and communicate data collected [2]. Voice recognition is a process that aims to identify 'who' is speaking. Speaker Verification uses the process of voice recognition to match the test input with a pre-recorded sample for verification or authentication. This falls under the domain of biometrics.

Cloud computing is the availability of resources like data storage and processing power, as per user requirements which is sourced from a remote location, over the internet. Cloud Storage and processing has allowed us to store a huge amount of data on a virtual storage device. This reduces the memory requirements in the wearable and makes it cheaper as compared to using local storage. The data needed is extracted from the cloud storage according to specific requirements. This also makes the data universally accessible and reduces the risk of losing data and evidence if the device is physically harmed under any circumstances.

Most of the IoT based devices developed for women safety make use of a mobile-based application to activate the system. This, however, reduces the utility of the device in case of emergencies as the usage of mobile phones in the presence of an attacker might not be feasible. Our system, on the other hand, does not use any mobile interface. It is strictly a hardware system that gets activated and starts functioning on customizable voice command. It is easier to activate and provides better safety [3].

This paper is divided into six sections. The next section covers the literature survey of the existing works. Section three describes the proposed solution. Section four covers the methodology for the proposed solution, including description of the hardware, software components and the procedure. Section five discusses the result of the implementation of the proposed solution. The last section concludes the paper, highlighting the novelty of the proposed solution.

\section{LITERATURE SURVEY}

There is a lot of work going on in different parts of the world to ensure women safety. Table-I gives a literature survey of the related works.

It gives is a comprehensive study of the related works and the advantages and disadvantages of the existing solutions.

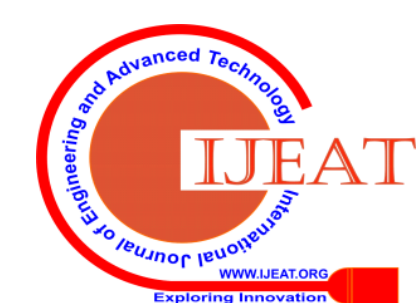


Table- I: Related Works Analysis

\begin{tabular}{|c|c|c|c|c|}
\hline S.No & Title & Method Used & Advantages & Disadvantages \\
\hline 1 & $\begin{array}{l}\text { 'WeRSafe' an Android App } \\
\text { for Society [4]. }\end{array}$ & $\begin{array}{l}\text { It proposes a } \\
\text { mobile-based } \\
\text { application to send } \\
\text { SOS calls and } \\
\text { messages to the } \\
\text { contacts on the press } \\
\text { of a button, through an } \\
\text { application. }\end{array}$ & $\begin{array}{l}\text { 1) It alerts the } \\
\text { contacts mentioned } \\
\text { by the user in case of } \\
\text { slight doubt, with just } \\
\text { a press of the button. } \\
\text { 2) It records video } \\
\text { and stores it in a } \\
\text { hidden memory not } \\
\text { easily discoverable by } \\
\text { the attacker. } \\
\text { 3) It has a lot of } \\
\text { features to share the } \\
\text { victim's story if } \\
\text { required (with } \\
\text { consent). } \\
\text { 4) It has a de-stress } \\
\text { button if safe. }\end{array}$ & $\begin{array}{l}\text { 1) It requires to press the button } \\
\text { for every aspect of this application } \\
\text { which is difficult in such } \\
\text { situations. } \\
\text { 2) In such situations, it is difficult } \\
\text { to press a button or respond to } \\
\text { smartphone devices. } \\
\text { 3) It requires a smartphone in all } \\
\text { situations and in case of the battery } \\
\text { down it is ineffective. } \\
\text { 4) The recording needs to be done } \\
\text { by smartphone but in such } \\
\text { situations to record a video } \\
\text { through a smartphone is not } \\
\text { possible in any case. }\end{array}$ \\
\hline 2 & $\begin{array}{l}\text { Smart security solution for } \\
\text { women based on Internet of } \\
\text { Things (IOT) [1]. }\end{array}$ & $\begin{array}{l}\text { It proposes the } \\
\text { development of a } \\
\text { smart band that } \\
\text { monitors human } \\
\text { behavior and reactions } \\
\text { to different situations } \\
\text { like fear, anxiety, } \\
\text { anger, etc. It transmits } \\
\text { the the } \\
\text { observed data to a } \\
\text { smartphone that is } \\
\text { connected to the } \\
\text { internet. These } \\
\text { reactions are } \\
\text { monitored using } \\
\text { biological measures } \\
\text { like heart rate etc. } \\
\text { It uses a GPS module } \\
\text { for tracking down the } \\
\text { victim and send an } \\
\text { ICE to the nearest } \\
\text { police station through } \\
\text { URL via accessing the } \\
\text { longitude and latitude } \\
\text { of the victim. }\end{array}$ & $\begin{array}{l}\text { 1) It completely relies } \\
\text { on biological } \\
\text { measures like a } \\
\text { heartbeat and does not } \\
\text { require any explicit } \\
\text { activation. }\end{array}$ & $\begin{array}{l}\text { 1) One of the major drawbacks in } \\
\text { this system is the dependence on } \\
\text { biological measures which can be } \\
\text { triggered by an intense workout, } \\
\text { surprises, weather conditions or } \\
\text { health issues that can thus generate } \\
\text { false alarms. } \\
\text { 2) The smartphone is required in } \\
\text { every aspect of its work. } \\
\text { 3) Internet is required in every } \\
\text { aspect of its working and is a } \\
\text { major drawback in the case of low } \\
\text { internet connectivity areas. } \\
\text { 4) There is no measure of recoding } \\
\text { and collecting evidence. } \\
\text { 5) The is no de-stress button for } \\
\text { false alarms as it can be triggered } \\
\text { through false alarms. } \\
\text { 6) It consumes battery power. }\end{array}$ \\
\hline
\end{tabular}




\begin{tabular}{|c|c|c|c|c|}
\hline 3 & $\begin{array}{l}\text { Women safety device and } \\
\text { application-FEMME [5]. }\end{array}$ & $\begin{array}{l}\text { It proposes a } \\
\text { mobile-based } \\
\text { application that sends } \\
\text { SOS calls and } \\
\text { messages to the } \\
\text { contacts on the press } \\
\text { of a button, through an } \\
\text { application } \\
\text { incorporating GPS, } \\
\text { GSM, Camera } \\
\text { recorder and Audio } \\
\text { recorder. It works by } \\
\text { the number of times } \\
\text { the volume up button } \\
\text { is clicked and does the } \\
\text { actions. }\end{array}$ & $\begin{array}{l}\text { 1) The device works } \\
\text { without the internet. } \\
\text { 2) When the battery is } \\
\text { low, it automatically } \\
\text { sends a default } \\
\text { message sharing the } \\
\text { last location of the } \\
\text { user. } \\
\text { 3) It records audio } \\
\text { and senses for hidden } \\
\text { cameras for evidence } \\
\text { proofing. }\end{array}$ & $\begin{array}{l}\text { 1) The need to use the smartphone, } \\
\text { which in such circumstances might } \\
\text { become difficult or impossible to } \\
\text { access in the presence of the } \\
\text { attackers. } \\
\text { 2) It is not feasible to record the } \\
\text { video/audio with the phone in such } \\
\text { situations. } \\
\text { 3) Sometimes, the buttons can be } \\
\text { accidentally pressed while kept in } \\
\text { pockets which would be a false } \\
\text { alarm and create problems. }\end{array}$ \\
\hline 4 & $\begin{array}{l}\text { IoT Based Women Safety } \\
\text { Device using ARM7 [6]. }\end{array}$ & $\begin{array}{l}\text { It proposes a } \\
\text { hardware-based } \\
\text { implementation in } \\
\text { which a button needs } \\
\text { to be pressed to alert } \\
\text { the location of the } \\
\text { victim using GPS, } \\
\text { GSM, } \\
\text { Microcontroller to } \\
\text { family and police with } \\
\text { activating the buzzer } \\
\text { of the alarm. }\end{array}$ & $\begin{array}{l}\text { 1) It has a minimal } \\
\text { setup. }\end{array}$ & $\begin{array}{l}\text { 1) It requires a button to be } \\
\text { pressed to activate the device. } \\
\text { 2) There is no measure of recoding } \\
\text { and collecting evidence. } \\
\text { 3) The activation of the buzzer can } \\
\text { be turned into a more dangerous } \\
\text { situation as the attackers may get } \\
\text { aggressive. } \\
\text { 4) It requires the involvement of } \\
\text { the victim for pressing the button. } \\
\text { 5) There is no de-stress button in } \\
\text { case it was a false alarm. }\end{array}$ \\
\hline 5 & $\begin{array}{l}\text { A Mobile Application for } \\
\text { Women's Safety: WoSApp } \\
\text { [7]. }\end{array}$ & $\begin{array}{l}\text { It proposes a solution } \\
\text { in which by shaking } \\
\text { the phone } 40 \text { times the } \\
\text { app will be triggered } \\
\text { and an audio message } \\
\text { will be sent to the } \\
\text { nearest police helpline } \\
\text { using the GPS } \\
\text { coordinates and also } \\
\text { to the pre-selected } \\
\text { emergency contacts a } \\
\text { text message. }\end{array}$ & $\begin{array}{l}\text { 1) Simple UI for } \\
\text { everyone. } \\
\text { 2) Fast and cheaper. }\end{array}$ & $\begin{array}{l}\text { 1) The smartphone is required to } \\
\text { run the application. } \\
\text { 2) The device needs shaking for at } \\
\text { least } 40 \text { times which can be } \\
\text { accidental as well as like } \\
\text { jogging/running and in such } \\
\text { situations not a better way to } \\
\text { counter. } \\
\text { 3) There is no measure of recoding } \\
\text { and collecting evidence. } \\
\text { I) requires an internet } \\
\text { connection for GPS location } \\
\text { tracking which in case of low } \\
\text { connectivity can be a major } \\
\text { problem. }\end{array}$ \\
\hline
\end{tabular}




\begin{tabular}{|c|c|c|c|c|}
\hline 6 & $\begin{array}{l}\text { Smart Girls Security System } \\
\text { [8]. }\end{array}$ & $\begin{array}{l}\text { It proposes a belt } \\
\text { which when activated, } \\
\text { tracks the location of } \\
\text { the victim and sends } \\
\text { the SOS to } 3 \\
\text { emergency contacts. It } \\
\text { has a screaming alarm } \\
\text { and generates the } \\
\text { electric shock to harm } \\
\text { the attacker. }\end{array}$ & $\begin{array}{l}\text { 1) User does not need } \\
\text { a smartphone. } \\
\text { 2) It has a shock } \\
\text { generating mechanism } \\
\text { to injure the attacker } \\
\text { in need of } \\
\text { self-defense. } \\
\text { 3) The belt has a } \\
\text { screaming alarm that } \\
\text { uses a real-time clock, } \\
\text { to call out for help. }\end{array}$ & $\begin{array}{l}\text { 1) The system will get activated } \\
\text { automatically when the threshold } \\
\text { of the pressure sensor will cross. } \\
\text { In the crowded areas, the belt will } \\
\text { trigger some fake alarms that may } \\
\text { end up giving trouble to the } \\
\text { emergency contacts and the crowd } \\
\text { around. } \\
\text { 2) There is no measure of recoding } \\
\text { and collecting evidence. } \\
\text { 3) It requires an internet } \\
\text { connection for GPS location } \\
\text { tracking which in case of low } \\
\text { connectivity can be a major } \\
\text { problem. } \\
\text { 4) There is a no de-stress button in } \\
\text { case it was a false alarm. }\end{array}$ \\
\hline 7 & $\begin{array}{l}\text { Smart Intelligent } \\
\text { Security System for Women } \\
\text { [9]. }\end{array}$ & $\begin{array}{l}\text { It proposes a system } \\
\text { that resembles a band } \\
\text { on the wrist } \\
\text { incorporated with } \\
\text { pressure switch as an } \\
\text { input which when } \\
\text { activates shows the } \\
\text { result Screaming } \\
\text { alarm and tear gas } \\
\text { mechanism are } \\
\text { imposed for } \\
\text { self-defense purposes } \\
\text { and send location and } \\
\text { messages to the } \\
\text { emergency contacts } \\
\text { and also figure out the } \\
\text { attacker using live } \\
\text { streaming video. }\end{array}$ & $\begin{array}{l}\text { 1) A live streaming } \\
\text { mechanism is used } \\
\text { here. } \\
\text { 2) The tear gas } \\
\text { mechanism is used for } \\
\text { self-defense. }\end{array}$ & $\begin{array}{l}\text { 1) A switch is there on the band } \\
\text { that is required to be activated. } \\
\text { May result in fake alarms. } \\
\text { 2) On fake trigger, tear gas will be } \\
\text { the problem for the people around } \\
\text { the user. } \\
\text { 3) Tear gas may affect the victim } \\
\text { itself. } \\
\text { 4) The activation of the switch can } \\
\text { be turned into a more dangerous } \\
\text { situation as the attackers may get } \\
\text { aggressive. } \\
\text { 5) There is no de-stress button in } \\
\text { case. It was a false alarm. }\end{array}$ \\
\hline 8 & $\begin{array}{l}\text { Intelligent Safety System to } \\
\text { Prevent Acid Attacks [10]. }\end{array}$ & $\begin{array}{l}\text { The device (wrist } \\
\text { band) incorporates } \\
\text { sensors for corrosive } \\
\text { assault and physical } \\
\text { badgering. It has GSM } \\
\text { and GPS module for } \\
\text { finding the casualty. } \\
\text { The unit can be } \\
\text { changed over to chip } \\
\text { utilizing framework } \\
\text { on chip (SOC) } \\
\text { innovation. }\end{array}$ & $\begin{array}{l}\text { 1) The acid detector } \\
\text { needs a sensitivity } \\
\text { adjustment for } \\
\text { avoiding fake alarms. }\end{array}$ & $\begin{array}{l}\text { 1) The system does not have any } \\
\text { features that can directly call } \\
\text { complete medical assistance at the } \\
\text { time of the casualty. } \\
\text { 2) The system is quite expensive } \\
\text { due to the use of ACID Sensor and } \\
\text { Tilt Sensor. } \\
\text { 3) It requires an internet } \\
\text { connection for GPS location } \\
\text { tracking which in case of low } \\
\text { connectivity can be a major } \\
\text { problem. }\end{array}$ \\
\hline
\end{tabular}




\begin{tabular}{|c|c|c|c|c|}
\hline 9 & $\begin{array}{l}\text { Women Security System } \\
\text { using GSM \& GPS [2]. }\end{array}$ & $\begin{array}{l}\text { A button is to be } \\
\text { pressed on the device. } \\
\text { In such a case, GPS } \\
\text { tracks the location of } \\
\text { the women \& sends an } \\
\text { emergency message } \\
\text { using GSM to saved } \\
\text { contacts \& police } \\
\text { control room. }\end{array}$ & $\begin{array}{l}\text { 1) Video recording } \\
\text { will start once the } \\
\text { button is pressed. }\end{array}$ & $\begin{array}{l}\text { 1) The activation of the switch can } \\
\text { be turned into a more dangerous } \\
\text { situation as the attackers may get } \\
\text { aggressive. } \\
\text { 2) There is no de-stress button in } \\
\text { case it was a false alarm. }\end{array}$ \\
\hline 10 & $\begin{array}{l}\text { IPROB }-\quad \text { Emergency } \\
\text { Application for Women [11]. }\end{array}$ & $\begin{array}{l}\text { If an emergency is } \\
\text { suspected a } \\
\text { notification is raised } \\
\text { requiring the user's } \\
\text { response. If the user } \\
\text { does not respond, the } \\
\text { system alerts } \\
\text { pre-specified social } \\
\text { contacts with an } \\
\text { informational message } \\
\text { via SMS. }\end{array}$ & $\begin{array}{l}\text { 1) Notification is } \\
\text { raised for the } \\
\text { confirmation of the } \\
\text { user, whether it's an } \\
\text { emergency or not. If } \\
\text { no response is } \\
\text { submitted, the system } \\
\text { alerts the social } \\
\text { contacts. } \\
\text { 2) When a message } \\
\text { called ALERT is } \\
\text { received it } \\
\text { automatically changes } \\
\text { the smartphone } \\
\text { profile to general, and } \\
\text { gives a voice } \\
\text { notification }\end{array}$ & $\begin{array}{l}\text { 1) A smartphone is required. } \\
\text { 2) Sometimes the phone may not } \\
\text { sense the emergency and does not } \\
\text { generate the notification itself on } \\
\text { the user's phone. }\end{array}$ \\
\hline 11 & $\begin{array}{l}\text { Smart foot device for women } \\
\text { safety [12]. }\end{array}$ & $\begin{array}{l}\text { This paper } \\
\text { demonstrates a } \\
\text { women safety device } \\
\text { that can be clipped on } \\
\text { to the footwear for } \\
\text { triggering an SOS } \\
\text { message in a discrete } \\
\text { manner case of an } \\
\text { attack. The alarm can } \\
\text { be triggered by } \\
\text { tapping one foot } \\
\text { behind the other four } \\
\text { times. The alert is sent } \\
\text { to an application on } \\
\text { the phone using } \\
\text { Bluetooth, and the } \\
\text { SOS message contains } \\
\text { the location of the } \\
\text { victim. The results } \\
\text { were analyzed using } \\
\text { naïve Bayes classifier } \\
\text { to calculate the } \\
\text { accuracy. }\end{array}$ & $\begin{array}{l}\text { 1) The components } \\
\text { involved in the system } \\
\text { are not expensive and } \\
\text { hence it is a low-cost } \\
\text { device. It will be } \\
\text { easily accessible to a } \\
\text { large portion of the } \\
\text { population. } \\
\text { 2) The proposed } \\
\text { system has a high } \\
\text { experimental } \\
\text { accuracy. } \\
\text { 3) The device is well } \\
\text { concealed, } \\
\text { physical access to a } \\
\text { smart phone is not } \\
\text { required. Hence the } \\
\text { alert may be sent } \\
\text { discretely. }\end{array}$ & $\begin{array}{l}\text { 1) There is a chance of triggering a } \\
\text { false alarm due to accidental } \\
\text { tapping of the foot. } \\
\text { 2) The training data needs to } \\
\text { incorporate different scenarios, } \\
\text { genders, ages, etc. to be more } \\
\text { accurate in detection. } \\
\text { 3) The usage of the proposed } \\
\text { system may be a challenge for } \\
\text { people with disabilities or injuries. }\end{array}$ \\
\hline
\end{tabular}




\begin{tabular}{|c|c|c|c|c|}
\hline 12 & $\begin{array}{l}\text { A Novel Approach to Provide } \\
\text { Protection for Women by } \\
\text { Using Smart Security Device } \\
\text { [13]. }\end{array}$ & $\begin{array}{l}\text { This system is } \\
\text { designed using a } \\
\text { variety of sensors in } \\
\text { order to ensure that } \\
\text { women do not feel } \\
\text { helpless in any } \\
\text { dangerous situation. It } \\
\text { uses } 5 \text { sensors, pulse } \\
\text { rate sensor, sound } \\
\text { sensor, } \\
\text { accelerometer, } \\
\text { temperature sensor, } \\
\text { flex sensor. If any } 4 \\
\text { out of these } 5 \text { sensors } \\
\text { crosses the threshold } \\
\text { value, the buzzer is } \\
\text { activated, and GPS } \\
\text { coordinates are sent to } \\
\text { the emergency contact } \\
\text { via GSM module. }\end{array}$ & $\begin{array}{l}\text { 1) The proposed } \\
\text { system uses data from } \\
5 \text { different sensors to } \\
\text { reduce the chance of a } \\
\text { false alarm. If some } \\
\text { two or three sensors } \\
\text { alert that the threshold } \\
\text { is crossed, the alarm is } \\
\text { still not triggered until } \\
\text { four sensors alert that } \\
\text { threshold is crossed. } \\
\text { 2) The proposed } \\
\text { system does not } \\
\text { require any user } \\
\text { action. It does not } \\
\text { require the user to } \\
\text { launch any } \\
\text { application or press } \\
\text { any button. In case of } \\
\text { an attack, the user } \\
\text { may not have an } \\
\text { opportunity to } \\
\text { manually trigger the } \\
\text { system. Hence this } \\
\text { system takes that issue } \\
\text { into account. }\end{array}$ & $\begin{array}{l}\text { 1) The sound sensor has a } \\
\text { threshold of 25-40 dB (given). } \\
\text { This threshold can be easily } \\
\text { crossed in any noisy city traffic } \\
\text { environment. The MEMS } \\
\text { accelerometer is used to measure } \\
\text { sudden fall but that can also be } \\
\text { falsely triggered in case the person } \\
\text { is involved in any activity (e.g- } \\
\text { sports) which involves sudden } \\
\text { acceleration. The pulse rate sensor } \\
\text { is also prone to false trigger in case } \\
\text { the person is under any stress or } \\
\text { undergoes any strenuous activity. } \\
\text { 3) The buzzer that gets triggered } \\
\text { may alert the attacker and cause } \\
\text { him to panic and worsen the } \\
\text { situation in haste. This may prove } \\
\text { to be counter-productive for the } \\
\text { user. }\end{array}$ \\
\hline 13 & $\begin{array}{llr}\text { An Android } & \text { Based } \\
\text { Application for } & \text { Women } \\
\text { Security [14]. } & & \end{array}$ & $\begin{array}{l}\text { This paper describes } \\
\text { an android application } \\
\text { for women safety that } \\
\text { triggers an alert on } \\
\text { shaking the mobile } \\
\text { phone. The } \\
\text { application alerts the } \\
\text { registered contacts } \\
\text { along with nearby } \\
\text { people who are users } \\
\text { of the application. }\end{array}$ & $\begin{array}{l}\text { 1) The application not } \\
\text { only alerts the } \\
\text { registered contacts } \\
\text { but also alerts nearby } \\
\text { people who have the } \\
\text { application installed. } \\
\text { This increases the } \\
\text { chances that the } \\
\text { victim gets help } \\
\text { immediately. } \\
\text { 2) It involves a } \\
\text { convenient method of } \\
\text { triggering an alert in } \\
\text { case of an attack. }\end{array}$ & $\begin{array}{l}\text { 1) Shaking the phone is a very } \\
\text { general motion and it may lead to a } \\
\text { lot of false alarms. } \\
\text { 2) The application is meant for a } \\
\text { smart-phone and requires an } \\
\text { internet connection. It might not } \\
\text { be always available. Hence the } \\
\text { application may not function } \\
\text { correctly in the absence of an } \\
\text { internet connection. }\end{array}$ \\
\hline
\end{tabular}

\section{PROPOSED SOLUTION}

The aim is to use upcoming concepts like Internet of things, Cloud Computing and Natural Language Processing to develop a working prototype of a smart wearable device for women that can help them in such situations and prevent such incidents from taking place. 'Rakshak' is an IOT based solution, which will help us to combat these situations effectively. It contains a GSM module, camera, microphone, GPS module, and Raspberry Pi.

The woman can activate a sequence of events using a voice command. The voice command will send out an SOS signal to the contact list, and nearby authorities. The help center to be contacted is determined by the location of the device obtained though GPS technology. The authorities can rush to the location of the incident and prevent the incident.
The camera will start recording as soon as the voice command is activated, and this data will be sent to cloud storage. In case the unfortunate incident takes place, the footage of this camera will serve as evidence against the attacker. In addition to preventing the incident, this device may create a sense of fear in their minds which may reduce the frequency of such incidents.As this device makes use of voice recognition module instead of using mobile applications for giving activation command, it becomes widely usable.

Thus, this solution can be used to make a women safety device using latest technologies.

Published By:

Blue Eyes Intelligence Engineering

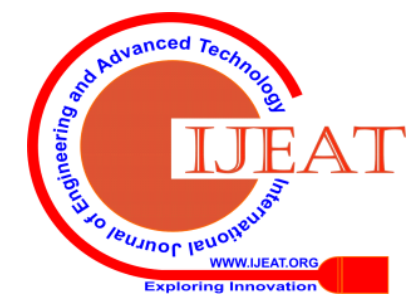




\section{PROPOSED METHODOLOGY}

The proposed methodology has been explained by dividing it into three parts- description of hardware components, description of software components and the procedure.

\section{A. Hardware Components Used:}

- Arduino Mega: It is a microcontroller with 54 digital pins connected to the other modules being used in the project.

- Voice Recognition Module V3: It is a hardware module that supports up to 80 voice commands in all. It can be controlled by Serial Port and General Input Output ports. Voice command is stored as a hex code which can then be used later.

- Neo6M GPS Module: It is used to retrieve the latitude and longitude details of the place. It can monitor about 22 satellites. It is suitable for low power devices.

- SIM800A GSM Module: It is used to make voice calls or SMS. Like mobile phones, it also needs a SIM Card to initial communication.

- Raspberry Pi: It is a single-board computer. It runs Linux and provides a set of GPIO pins. It is used in the project to communicate and store images to the cloud. A simple version of Pi 0 can also be used in the project.

\section{B. Software Components Used:}

- Arduino IDE: It is the integrated development environment that is used to write the program to be uploaded to the Arduino. It provides options to compile, verify, and upload the code. It provides many libraries to use the desired modules.

- Cloud Platform: Dropbox cloud platform is used to store evidence images and videos.

\section{Procedure:}

- The central element of the project is an Arduino Mega. This Module is required as there are more input/ output lines which cannot be accommodated in the commonly used Arduino Uno.

- The project functionality is to be activated through a voice recognition module. The module is first trained with the keywords which will be used to generate a number between 0 and79 as it can store 80 commands at a time. This module is connected to the Arduino and used to give the input through the $\mathrm{Rx}$, Tx pins.

- The GSM and GPS modules are used for sending SMS to the relatives and nearest help center. GPS module gets the location coordinates of the person which are in turn sent to through SMS by the GSM module using a SIM. It establishes a connection between the computer system and the mobile device to transfer this message and this feature is used to achieve our desired functionality even when mobile data networks are absent.

- Arduino Mega with a total of 54 pins is used. The voice recognition module has $\mathrm{Rx}$, Tx pins and they are connected to 10, 11 pins of the Arduino, respectively. It is also connected to an external power supply.

- Fig 1 shows the circuit diagram of the proposed device.

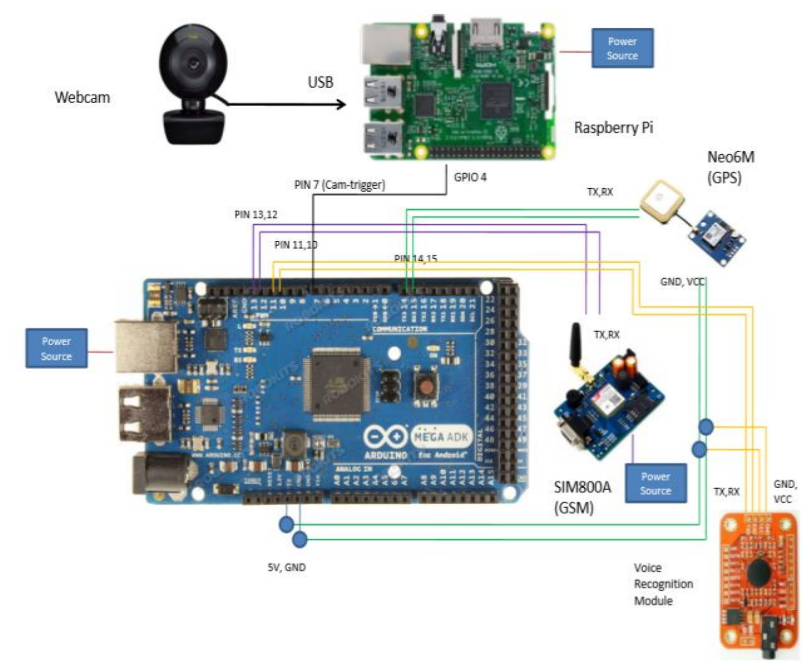

Fig. 1. Circuit Diagram

- The GPS module (Neo6M) is connected to VCC and GND for power and the Rx, Tx pins of the module are connected to Tx3 and Rx3 pins of the Arduino, respectively. The GSM module has its $\mathrm{Rx}$, Tx pins connected to the 12,13 pins.

- The camera is connected to the raspberry pi which gets a trigger input from the Arduino. This is connected to pin 7 of the Arduino. The webcam captures the image which is then uploaded to the cloud by the raspberry pi [4].

\section{RESULT AND DISCUSSION}

The methodology described above is implemented using the components described. This provides us with a proof of concept for the usability and functionality of the device which can further be enhanced by miniaturization.

The different steps followed for achieving the objectives of the project are:

- Device Setup: This step involves setting up the system by making all the connections as shown in the circuit diagram.

- Device Initialization: This step shows the initialization of the device which acts as the initial state of the system before any activation. The activation has been shown in Fig. 2 and Fig. 3.

- Device Activation: The activation of the device takes place when the voice recognition module detects the activation keyword. All the components explained above function concurrently on receiving this activation keyword. This state of the device is shown in Fig. 4 and Fig. 5.

- Coordinates Retrieval and Messaging: The SOS message received is shown in Fig. 6. It shows the location in the form of a google link which is easy to use.

- Dropbox Storage: This step includes capturing the image or video by the camera and storing it in the cloud storage for further evidence. This step has been shown in Fig. 7 and Fig 8.

Published By:

Blue Eyes Intelligence Engineering

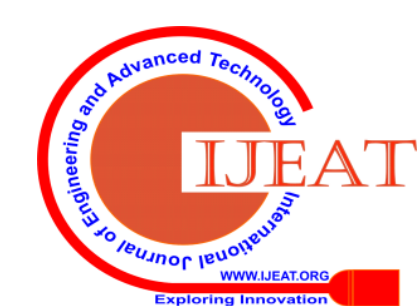




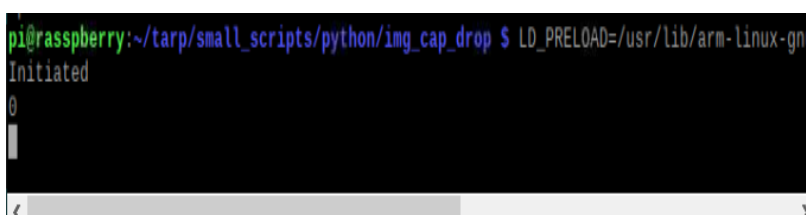

Fig. 2. Raspberry Pi Initialization

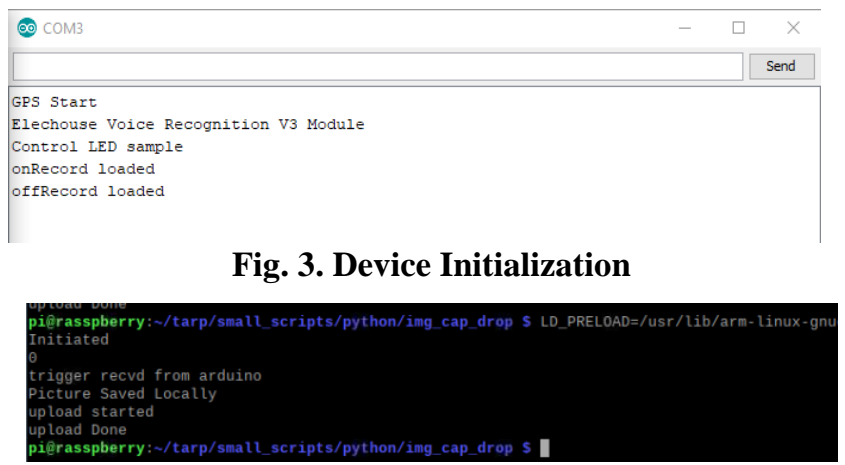

Fig. 4. Raspberry Pi Activation

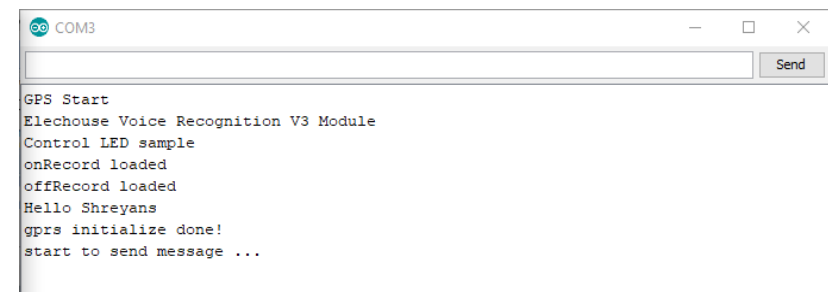

Fig. 5. Device Activation

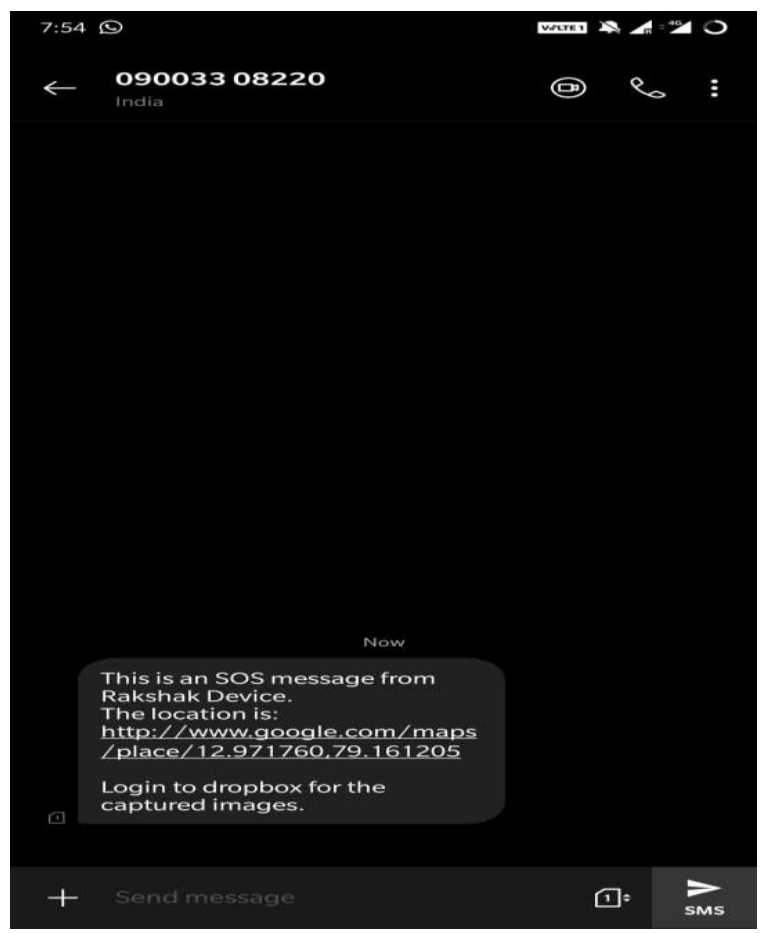

Fig. 6. SOS Message Receive

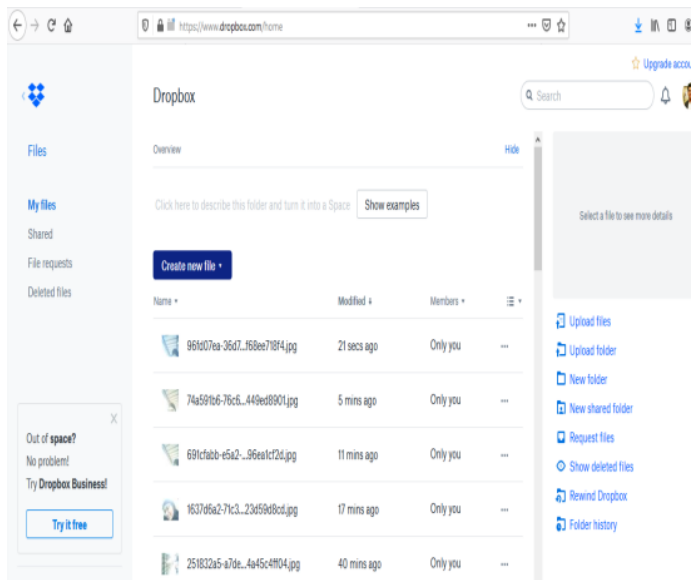

Fig. 7. DropBox Storage

96fd07ea-36d7-43f0-b5a8-60468ee718f4.jpg

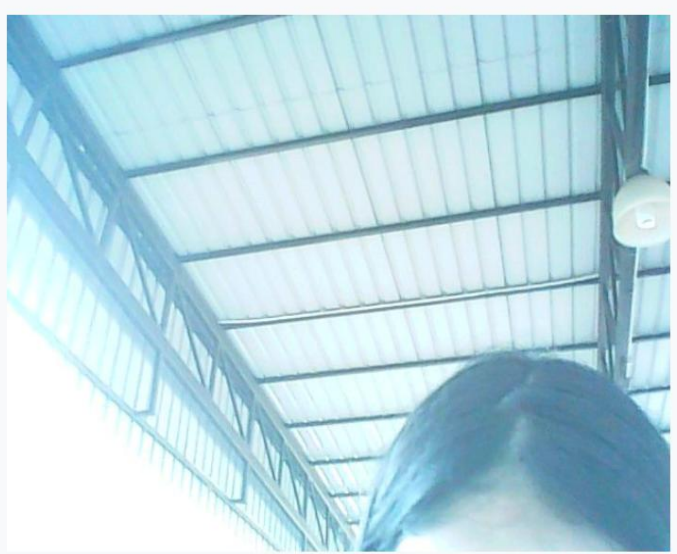

Fig. 8. Dropbox Image

Some future work that can be done in this project are:

- Miniaturization can be performed to make the device more usable.

- Data analysis facilities can be incorporated. It can alert women about crime hotspots when around them using GPS facilities.

\section{CONCLUSION}

It has been observed that using smart phones to ensure safety in the case of emergency is not feasible. Thus, the project Rakshak can be used as a wearable device for women safety which not only overcomes the problem and inconvenience of using a smart phone by using voice activation but also makes sure to store evidence for further legal proceedings along with common features like location tracking and SOS message sending. The device makes use of Internet of Things and Cloud Storage Technologies for the implementation purposes which saves the device contacts at a remote location and makes them easy to update. Thus, the device becomes more efficient and scalable. The feature of voice recognition for activation is brings novelty to this solution for women safety and makes it more personalized. These features make the device and efficient solution which can be used to ensure women safety.

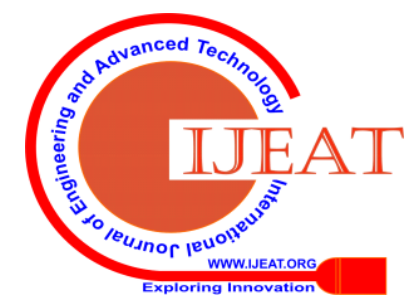




\section{REFERENCES}

1. G. C. Harikaran, K. Menasinkai and S. Shirol, "Smart security solution for women based on Internet Of Things (IOT)," in International Conference on Electrical, Electronics, and Optimization Techniques (ICEEOT), 2016.

2. G. P. B, S. N, T. E, R. S and S. a. C, "Women Security System using GSM \& GPS.," International Journal of Advanced Research Trends in Engineering and Technology, vol. 3, no. 19, 2016

3. Thomas, K. M. J, N. S. Vijayan and d. R., "TOUCH ME NOT-A Women Safety Device," International Research Journal of Engineering and Technology , vol. 5, no. 3, 2018.

4. T. Dey, T. Paul, S. Mukherjee and U. Bhattacharjee, "'WeRSafe' An Android Apps for Society," International Journal of Emerging Trends \& Technology in Computer Science, 2016.

5. D. G. Monisha, M. Monisha, P. Gunasekaran and S. Radhakrishnan, "Women safety device and application-FEMME," Indian Journal of Science and Technology , vol. 9, 2016.

6. S. Sharma, F. Ayaz, R. Sharma and D. Jain, "IoT Based Women Safety Device using ARM7," International Journal of Engineering Science and Computing, vol. 7, no. 5, 2017.

7. D. Chand, S. Nayak, K. S. Bhat, S. Parikh, Y. Singh and A. A. Kamath, "A mobile application for Women's Safety: WoSApp," in IEEE, 2015

8. B. Chougula, A. Naik, M. Monu, P. Patil and P. Das, "SMART GIRLS SECURITY SYSTEM," International Journal of Application or Innovation in Engineering \& Management, vol. 3, no. 4, 2014.

9. G. P. Miriyala, P. V. Sunil, R. S. Yadlapalli, V. R. L. Pasam, T. Kondapalli and A. Miriyala, "SMART INTELLIGENT SECURITY SYSTEM FOR WOMEN," International Journal of Electronics and Communication Engineering \& Technology, vol. 7, no. 2, 2016.

10. M. Pradeep, R. Abhinaya, S. S. Anandhi and S. Soundarya, "Intelligent Safety System to Prevent Acid Attacks," Asian Journal of Applied Science and Technology, vol. 1, no. 3, pp. 243-248, 2017

11. M. K. S. and R. K. M., "IPROB - Emergency Application For Women," International Journal of Scientific and Research Publications, vol. 4, no. 3, 2014

12. N. Vishwanath, N. V. Pakyala and G. Muneeswari, "Smart foot device for women safety," in 2016 IEEE Region 10 Symposium (TENSYMP), Bali, 2016

13. K. Seelam and K. Prasanti, "A novel approach to provide protection for women by using smart security device," in 2nd International Conference on Inventive Systems and Control (ICISC), Coimbatore, 2018

14. S. Mehta, S. Janawade, V. Kittur, S. Munnole and S. Basannavar, "An Android Based Application for Women Security," International Journal of Engineering Science and Computing, vol. 7, no. 6, 2017.

\section{AUTHORS PROFILE}

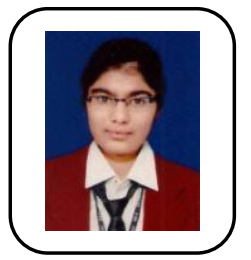

Ambika Singhal pursuing B.Tech in Computer Science and Engineering in Vellore Institute of Technology, Vellore. She is currently in her third year. She has decent knowledge of Data Structures and Algorithms. She likes to work in the domain of application development and has worked on several industrial and personal projects in domain. She worked as an intern at Campus Labs Pvt. Ltd. on a project dealing with java application development. She is also a board member of a student chapter IETE-VIT operating at VIT, Vellore. She has also organized many technical and non-technical events on national level as a member of the student chapter.

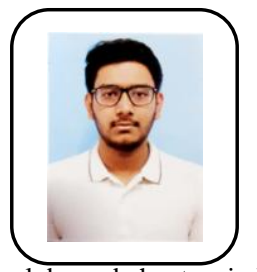

Shreyans Jain is a student of B.Tech in Computer Science and Engineering in Vellore Institute of Technology, Vellore. He has keen interest in the fields of Internet of Things (IoT) and Web Development. He has worked on multiple IoT and web-based projects. He worked as a web development intern at Innoraft Solutions Pvt. Ltd. He has held leadership roles in prominent technical clubs and chapters in VIT, like IETE-ISF, VIT Linux Users Group. He feels the need to provide solutions for societal problems with the use of appropriate technology.

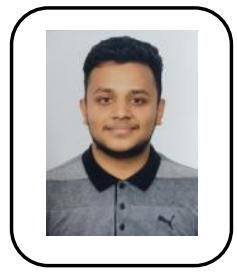

Keshav Agarwal pursuing B.Tech in Computer Science and Engineering with specialization in Information Security in Vellore Institute of Technology, Vellore. He is interested in domain of information security and has worked on several projects in the field of cyber security and cryptography. He has published a paper on Optimized Support Balance Model for Sensitive Rule Hiding in the field of Data Privacy. he has high proficiency in web development and has decent knowledge of Human Computer and Interaction. He was a former technical and management core committee member of ISA-VIT operating at VIT, Vellore and has conducted many events at national and university level. 